
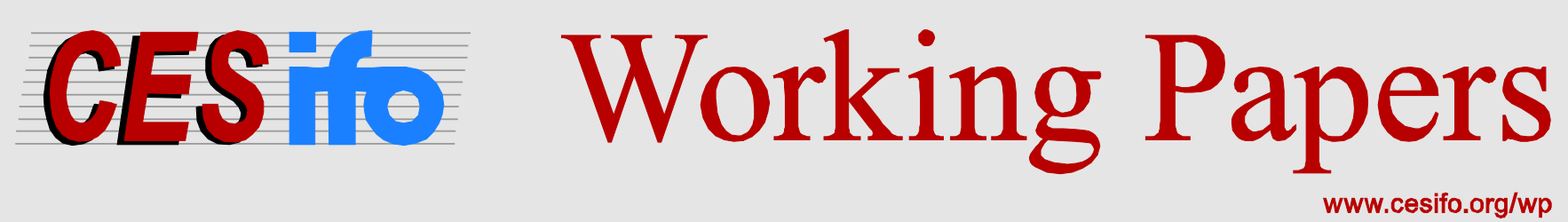

\title{
Management of the External Value of the Renminbi
}

\author{
Heikki Oksanen
}

\author{
CESIFO WORKING PAPER NO. 5325 \\ CATEgORY 7: MONETARY POLICY AND INTERNATIONAL FINANCE \\ APRIL 2015
}
An electronic version of the paper may be downloaded
- from the SSRN website:
- from the RePEc website:
- from the CESifo website:
wWw.SSRN.com
www.RePEc.org
www.CESifo-group.org/wp




\title{
Management of the External Value of the Renminbi
}

\begin{abstract}
Pegging the renminbi (RMB) to the US dollar since 1994 has characterised China's exchange rate policy, under either a fixed peg or appreciating crawling peg. The current policy, announced in June 2010, of 'floating with reference to a basket' has now in April 2015 made the RMB 19 per cent stronger against a trade-weighted basket, while it is nine per cent stronger against the USD. Ten percentage points thus arise from changes in the cross rates of the other currencies. This effect could be eliminated by managing the external value of the RMB with reference to a genuine broad basket. This could be a suitable intermediary exchange rate regime for China as the risks of jumping to free floating are still great. Diversifying further the currency composition of the foreign exchange reserves and other foreign assets of the Chinese government, from USD towards EUR and JPY assets, would be a natural parallel shift. The current EUR-USD-JPY exchange rates may offer a good opportunity to carry out this move.
\end{abstract}

JEL-Code: F300, F310, F330, F420.

Keywords: China, renminbi, yuan, basket peg, foreign exchange rates.

\author{
Heikki Oksanen \\ University of Helsinki / Finland \\ hkk.oksanen@gmail.com
}

This version: 16 April 2015. This paper is an update of my paper in Asian-Pacific Economic Literature, May 2012. I have benefitted greatly of comments from many colleagues, including those received in various conferences before and after spring 2012. The views expressed are my own and do not necessarily reflect the position of the European Commission, my former employer, where I worked as a research adviser. 


\section{Introduction}

The Peoples’ Bank of China (PBC) has gradually, over the past ten years, made the exchange rate of the renminbi (RMB) more flexible. As the latest systemic move it announced in March 2014 that the daily floating band of the RMB-USD rate was enlarged to \pm 2 per cent around the central rate set by the PBC, as compared to the \pm 1 per cent set in in April 2012.

Having pegged the RMB firmly to the USD since 1994 the PBC announced in July 2005 that the value of the RMB be set with reference to a basket of other currencies. This lasted until July 2008, when the RMB was again firmly pegged to the USD. The current system of 'managed floating based on market supply and demand with reference to a basket of currencies' was reintroduced on 19 June 2010. The composition of the basket has not been announced.

Oksanen (2012) showed that both in the first 'basket peg' period and from June 2010 onwards the observations display a crawling peg against the USD, with smooth appreciation most of the time, rather than pegging to a broader basket. More precisely, daily observations indicate that the weight of the USD in the basket has been roughly 90 per cent. The authorities never formally declared the trend-wise appreciation against the USD as their objective. $^{1}$

Over the past ten years the RMB has appreciated significantly by any measure and the current account surplus that was close to 10 per cent relative to GDP over several years 2006-2008 has now decreased to around 2 per cent. Several commentators consider that the RMB may no more be undervalued. However, important issues still remain open:

- the consequences of gradual appreciation for the capital inflows and how the PBC has tried and reduce them, while at the same time liberalising capital movements and promoting international use of the RMB;

- the composition of the basket that could be used as the reference both by the PBC in future and by outsiders for analysing the external value of the RMB; this issue is directly linked to the movements of the EUR-USD exchange rate;

- the composition of the RMB basket is linked to the composition of the foreign exchange reserves held by the PBC; also this is unknown, but it is widely assumed that a gradual shift away from the dominance of the USD has been taking place and may continue; also this is linked to the recent movements of the EUR-USD exchange rate.

These issues are discussed in the present short paper with ample reference to statistical data.

\footnotetext{
${ }^{1}$ Some studies on the July 2005 - July 2008 period referred to in Oksanen $(2012,23)$ had concluded that the EUR had gained a significant weight in the RMB basket, but he shows with graphs that this obviously resulted rather from spurious correlation than from a genuine change towards a broader basket.
} 


\section{A brief history of the external value of the RMB and China's balance of payments}

\section{$2.1 \quad$ Before 2010}

The official exchange rate system of the RMB was unified from the beginning of 1994. From mid-1995 until July 2005 pegging the RMB at 8.3 to the USD led first to appreciation of the RMB in effective terms until 2001 (both in nominal and real terms, see Figure 1; for the major currencies see Figure 2). ${ }^{2}$ From 2001 to July 2005 the RMB, being pegged to the weakening USD, the RMB lost one fifth of its value measured against a trade-weighted basket. China's economy was booming. Towards the end of this period the current account surplus increased consistently and also capital inflow boosted China's foreign exchange reserves. They exceeded 30 per cent relative to GDP (measured in USD) in June 2005. Practically all the accumulation had taken place since 1998 (Table 1).

From July 2005 the foreign exchange reserves increased strongly due to both current account surpluses and the inflow of capital, reaching 37 per cent relative to GDP in December 2014. About 85 per cent of reserves at the end of 2014 result from their accumulation since 2005Q2. The current account surplus as a percentage of the GDP gradually declined. Most interestingly from the point of view of managing the external value of the RMB, we note the occasional large inflows of capital, with fluctuations that can often be associated with appreciation of the RMB against the USD (Figure 3). Here, the expectations of making speculative profits obviously played an important role.

At the latest in 2005 the authorities considered that a current account surplus and reserve accumulation at the previous levels were not necessarily desired and a correction to the exchange rate was initiated. In July 2005 the value of the RMB against the USD was raised by 2 per cent and its management 'with reference to a basket of currencies' was announced. The crawling peg against the USD produced an appreciation by 20 per cent by July 2008, but as the USD still weakened against other currencies the RMB appreciated in effective terms only by 10 per cent. This meant that in July 2008 it was still weaker than in 2000-2002 (Figure 1). In 2005-2008 the current account surpluses were running at the level of some seven per cent relative to GDP (Figure 3).

\footnotetext{
${ }^{2}$ In Figures 1-2 and 4-5 the unit of account is RMB. Thus, a line for another currency or basket going down means appreciation of the RMB against it, and vice versa. In the text we refer to numbers expressed this way, but it should be noted that, for example, depreciation of any currency against the RMB by 25 per cent means that the RMB has appreciated against that particular currency by 33 per cent.
} 
Figure 1. The USD, SDR and trade-weighted basket against the RMB since 1994

monthly averages; indexes: averages 1998-2014 = 100; last observations March 2015

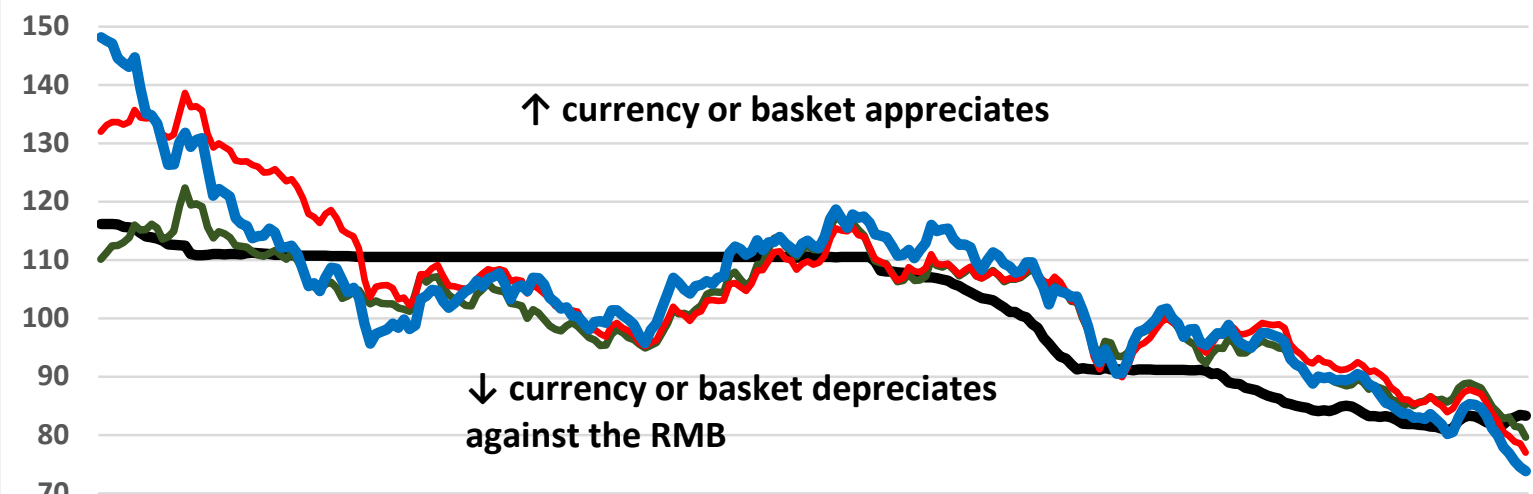

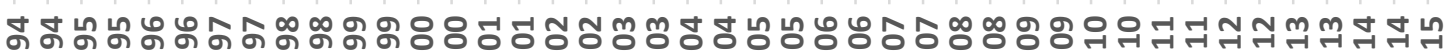

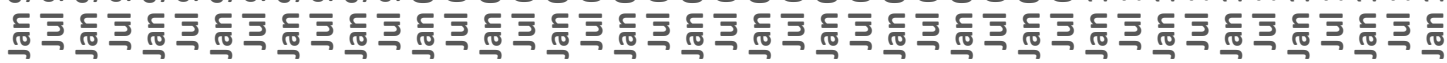

$\longrightarrow$ USD $\longrightarrow$ SDR $\longrightarrow$ NEER-basket $\rightleftharpoons$ REE-basket

Legend: the unit of account is the RMB; NEER-basket refers to 'nominal effective exchange rate' for the RMB, and REER-basket to 'real effective exchange rate'.

Sources: for the currencies and the SDR: European Central Bank and International Monetary Fund; for NEER and REER, Bank for International Settlements.

Figure 2. The USD, EUR, JPY, GBP and SDR against the RMB since 1994

monthly averages; indexes: averages 1998-2014 = 100; last observations March 2015

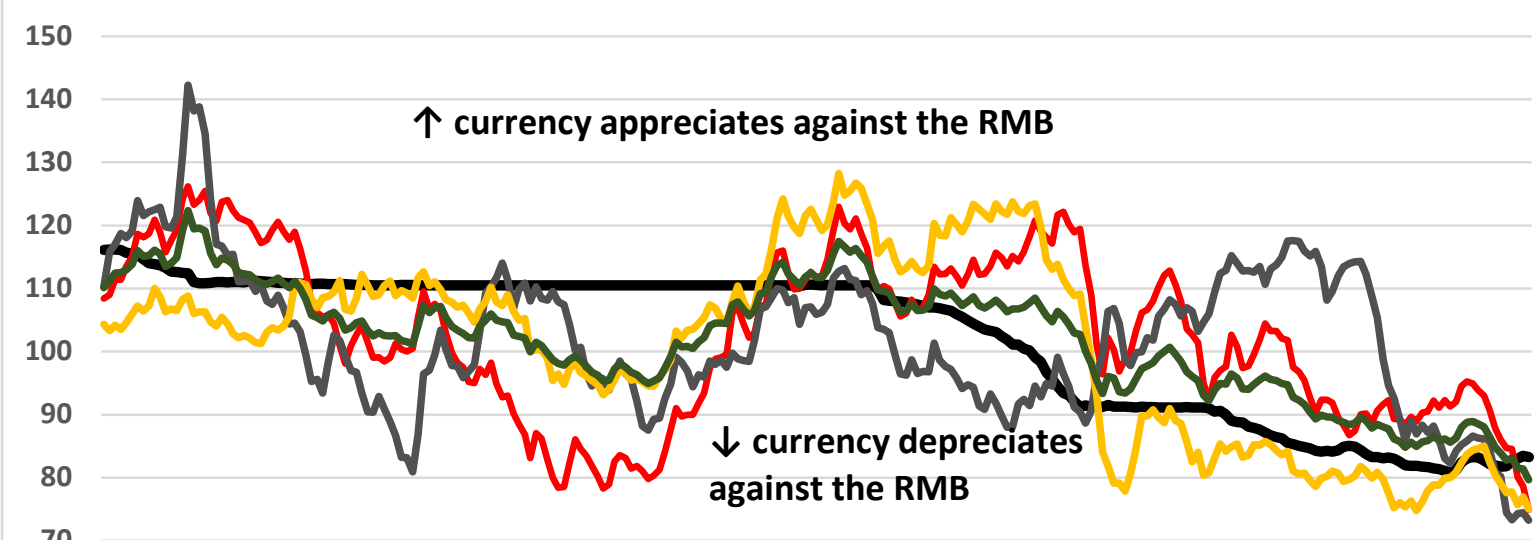

70

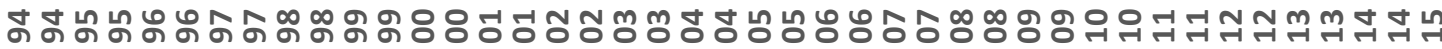

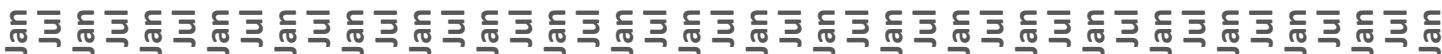

$\longrightarrow$ USD $\longrightarrow$ EUR $\longrightarrow$ GBP

Legend: the unit of account is the RMB.

Source: European Central Bank (ECB) and International Monetary Fund; for the EUR before 1999 ECB calculation based on the respective currencies. 
Table 1. China's balance of payments

accumulated sums of major items over selected periods

\begin{tabular}{|l|l|l|l|}
\hline Billions of USD & \multicolumn{3}{l|}{ till 2014Q4 from } \\
\hline & 1998Q1 & 2005Q3 & 2010Q3 \\
\hline Increase in FX reserves (BOP data) & 3826 & 3246 & 1327 \\
\hline of which & & & \\
\hline cumulative current account & 2576 & 2285 & 888 \\
\hline cumulative capital \& financial accounts \& net errors & 1249 & 961 & 439 \\
\hline of which capital \& financial account & 1644 & 1355 & 781 \\
\hline and net errors \& omissions & -297 & -297 & -342 \\
\hline
\end{tabular}

Source: China's balance of payments data, quarterly, State Administration of Foreign Exchange. Note: Level of FX reserves according to FX reserves data at the end of 2014 was USD bn 3843. This is close to the accumulation since 1998Q1 calculated from the balance of payments data even though the two figures are conceptually different.

Figure 3. Balance of payments of China, main items, quarterly, 2005Q1-2014Q4

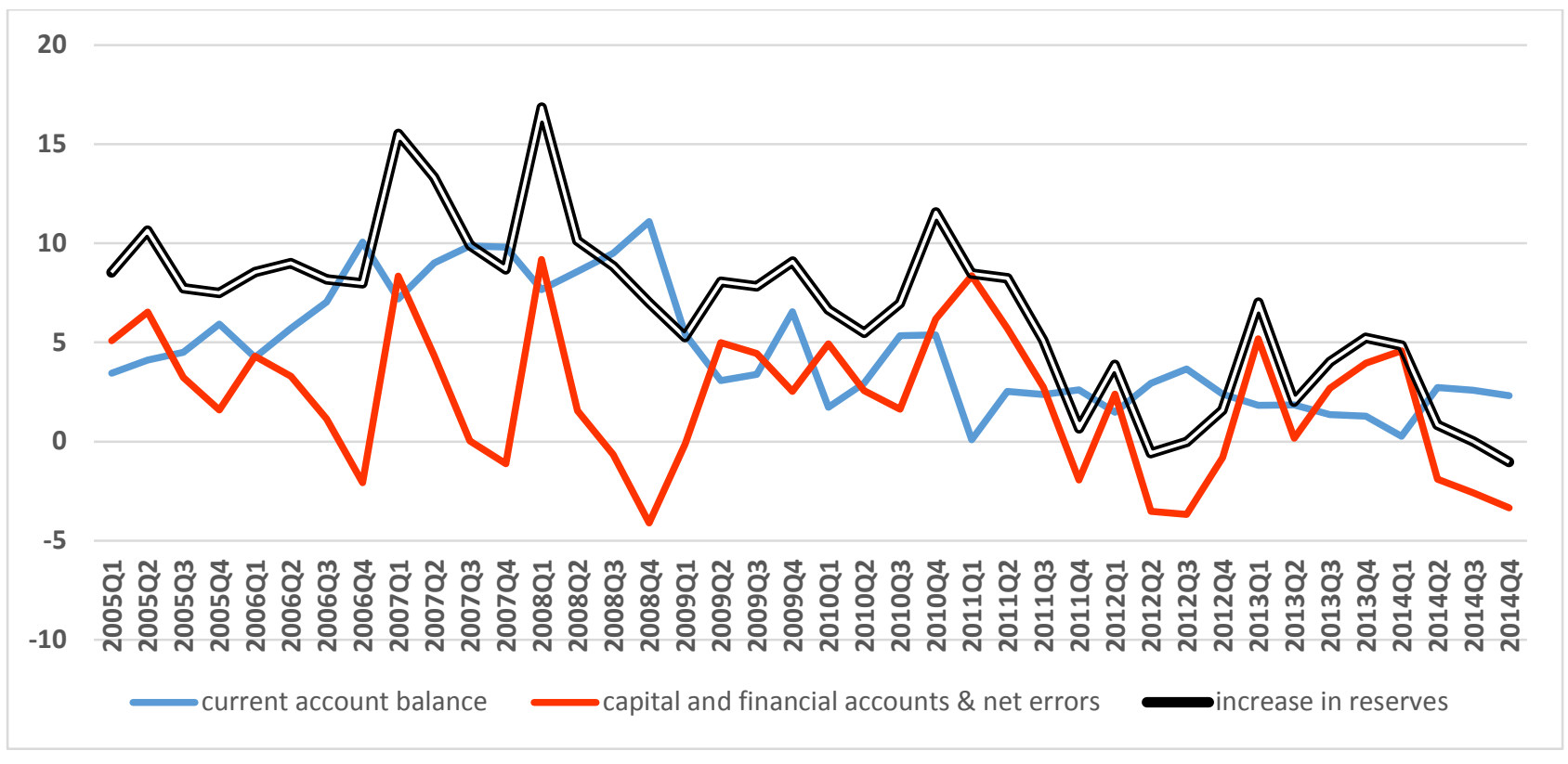

Legend: quarterly figures as per cent of GDP trend level. GDP trend by quarter is imputed from average growth from 1998 to 2014.

Source: State Administration of Foreign Exchange.

Over the period from July 2005 to July 2008, during the first period of managing the RMB with 'reference to a basket', capital inflows (together with errors and omissions in the statistics) were quite volatile, so the link to expectations of exchange rate changes is not clear. The reason might be that capital movements were still relatively tightly controlled. Also, then and later, the stepwise relaxation of controls may have caused part of the volatility 
of the recorded flows. Yet, on average over this period capital inflow was significant, nearly 3 per cent relative to GDP.

In July 2008 the RMB was firmly re-pegged to the USD amid the looming financial crisis. After Lehman Brothers collapsed, over the subsequent six months, the USD appreciated especially against the EUR (and the GBP). This made the RMB appreciate in effective terms by another ten per cent (Figure 1).

From 2008Q3 to 2010Q2 the current account surplus was still a significant five per cent relative to GDP, and also capital inflows were occasionally large.

\subsection{Re-pegging to the basket in $\mathbf{2 0 1 0}$}

In spring 2010 the Chinese authorities became concerned about the consequences of a possible fall of the EUR at the eruption of the Greek crisis. By early June 2010 the EUR had depreciated against the USD by 13 per cent in less than three months (Figure 4). One possible motivation behind the 19 June 2010 announcement was to enable a depreciation of the RMB against the USD if it still continued to appreciate significantly against the EUR. Two Chinese economists, Jianwei $\mathrm{Li}$ and $\mathrm{Bin} \mathrm{Yu}$, at a think tank under the State Council stated (writing before the 19 June 2010 announcement of the PBC): 'If there is large-scale euro depreciation against the dollar, we should progressively increase the flexibility of the renminbi's exchange rate and maintain the renminbi's nominal effective exchange rate at a reasonable, balanced level' (quoted by Reuters, 7 September 2010). This way the Chinese authorities would have preserved competitiveness of Chinese products in European and other markets. By giving a significant weight to the EUR in the RMB basket the Chinese authorities could have justified depreciation against the USD in the event of a further fall of the EUR.

This possible motivation for and timing of abolishing the fixed peg to the USD is logical. However, we cannot infer as to how important this argument was because exactly the opposite first occurred for the EUR-USD rate. It took four and a half years, until early 2015, for the value of the EUR to finally fall significantly below the 18 June 2010 level against the USD. Meanwhile, the RMB first depreciated in effective terms (i.e. against a basket of currencies), despite appreciating against the USD, mostly because the EUR and the JPY appreciated significantly. Only from July 2011 onwards has the RMB been in effective terms stronger than on 18 June 2010 (Figures 4 and 5). 
Figure 4. Various currencies and baskets against the RMB since 18 June 2010, daily

18 June 2010 values = 100; last observations 15 April 2015

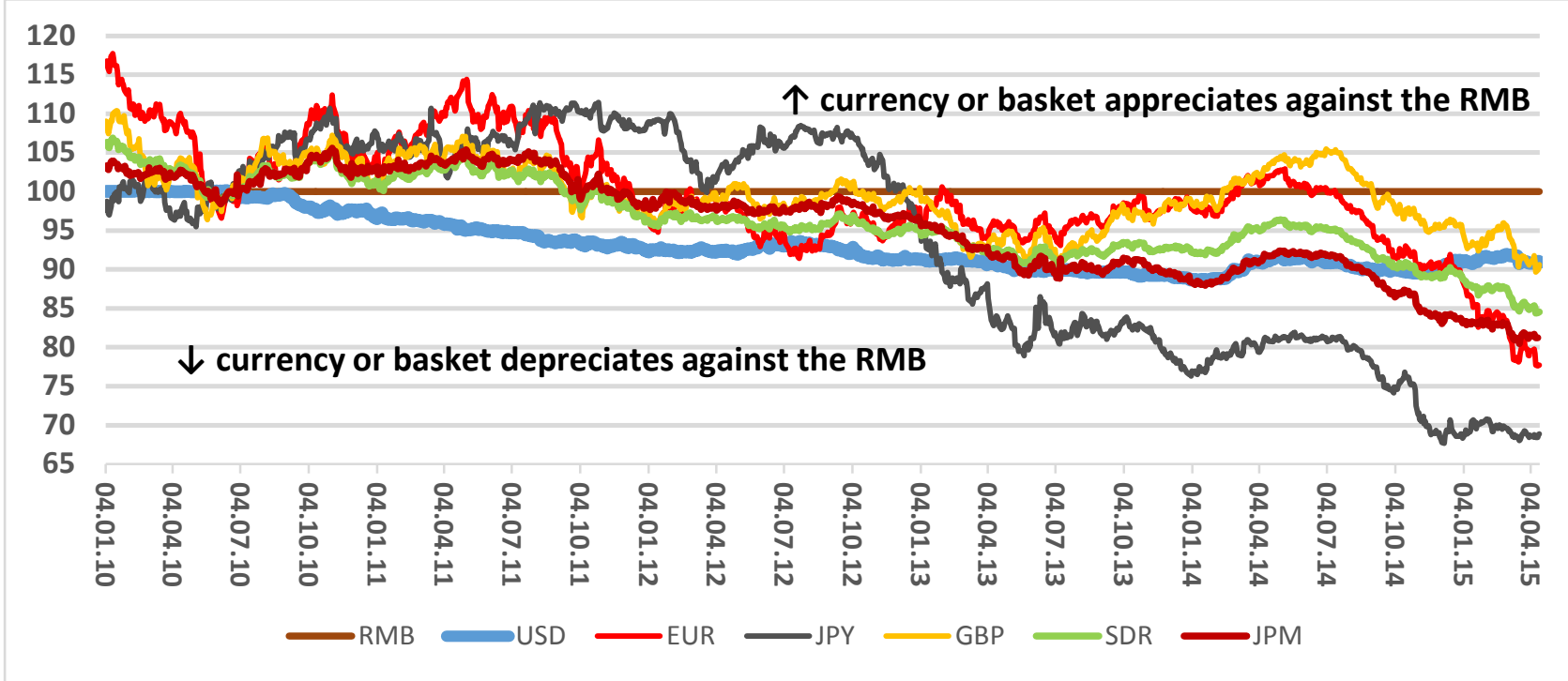

Legend: the unit of account is the RMB.

Sources: for the daily exchange rates European Central Bank; for the SDR International Monetary Fund and own calculations based on the share of the currencies in the SDR basket. JPM index is the RMB value of a broad trade-weighted basket of currencies as calculated by JP Morgan; source Bloomberg.

Figure 5. The USD, SDR and a trade-weighted basket against the RMB from 18/06/2010 daily observations; indexes 18/06/2010 = 100; last day is 15 April 2015

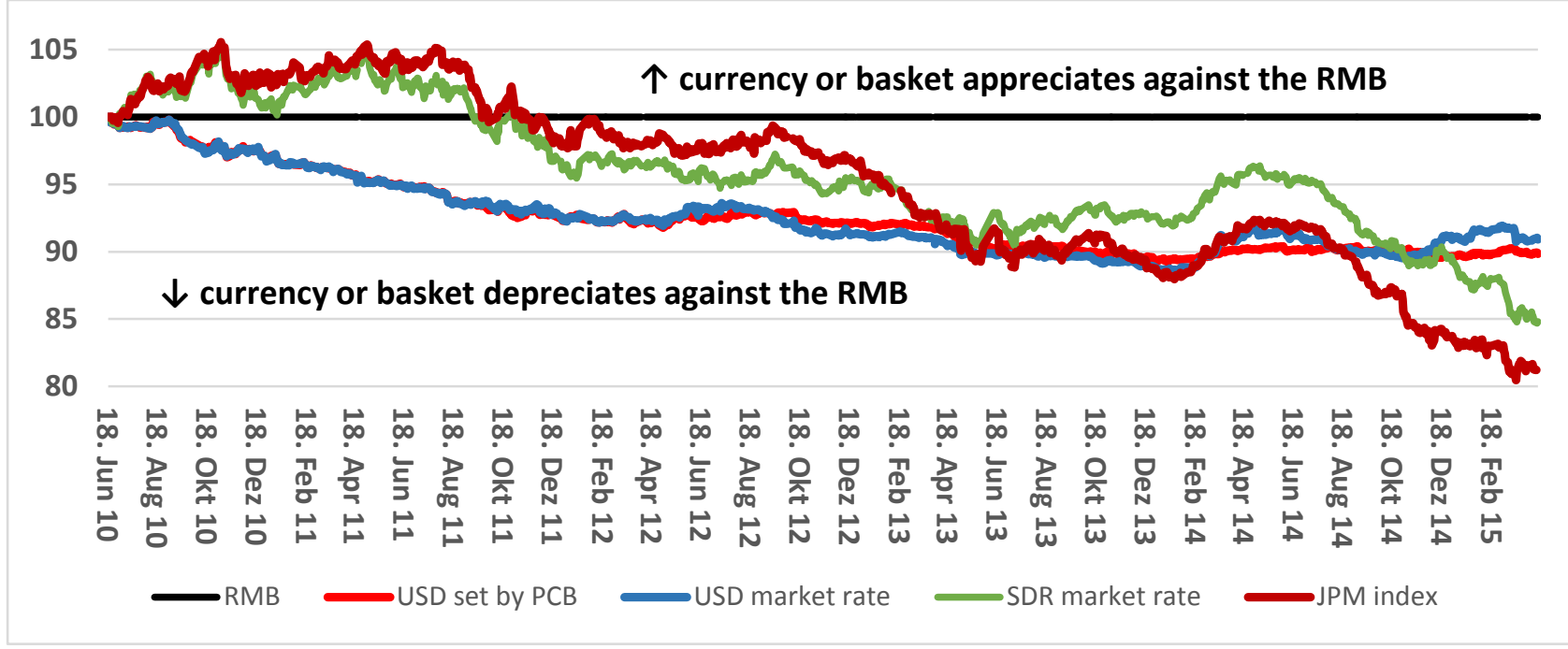

Legend: line down (up) indicates depreciation (appreciation) of the currency or a basket against the RMB.

Sources: for the PBC rates the State Administration of Foreign Exchange; for the market rates the European Central Bank. JPM index is the RMB value of a broad trade-weighted basket of currencies. 
Figure 6. Position of the RMB within the fluctuation band set by the PCB

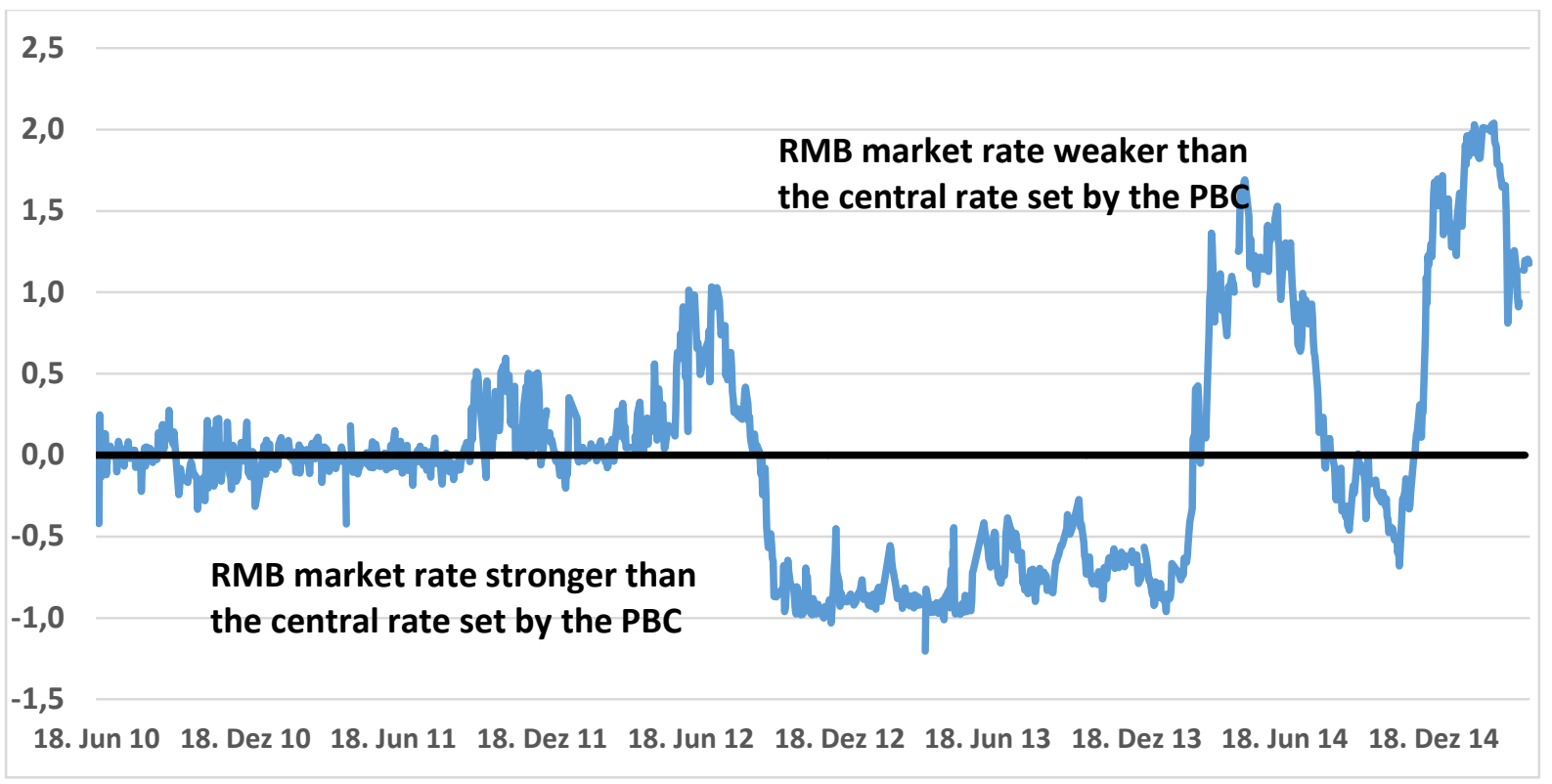

Legend: percentage difference between the RMB-USD market rate and the central rate set by the PCB, daily observations, 18 June 2010 - 15 April 2015.

Sources: Chinese State Administration of Foreign Exchange for the PBC rates and European Central Bank for the market rates.

\subsection{Enlarging the fluctuation band in 2012 and 2014}

For almost two years after June 2010 the RMB appreciated relatively steadily against the USD at about a five per cent annual rate (Figures 4 and 5). The current account surplus became more moderate, but the capital inflow in 2010Q3-2011Q3 was nearly five per cent relative to GDP. On 14 April 2012 the PBC announced that the fluctuation band for the daily RMB-USD rate was enlarged from \pm 0.5 to \pm 1 per cent, obviously to make the risk for the speculators two-sided (see the official announcement under References). The steady appreciation against the USD in the PBC quotations practically ended and even slightly reversed. A significant net outflow of capital followed over the subsequent three quarters. Regarding the question about the reasons behind this policy change we may note that the EUR had depreciated, but in April 2012 the value of the RMB against a trade-weighted basket was still only slightly below its level in June 2010 (see JPM index in Figures 4 and 5). So, there was no particular reason to be concerned about competitiveness of the Chinese industry, but the best hypothesis is that eliminating inflow of speculative capital was the main motivation behind the policy change in spring 2012.This policy worked, but only for a short time. Under the new conditions the deviation of the daily exchange rates in the market from the central rate set by the PBC give us information of market conditions. Over the summer 2012 the RMB market rate was touching the weaker limit of the band and capital was flowing out (Figures 3 and 6). This, however, lasted only until autumn. The market rate strengthened again in September 2012 and capital outflow ceased. In 2013 until the first quarter 2014 the RMB was trading close to the stronger limit of the band and capital was flowing in again. 
Part of the explanation must be the renewed steady appreciation of the RMB in the PBC central rate quotations for the USD from October 2012 until early 2014 (Figure 6). This was only less than three per cent at an annual rate, but it was steady. Under the gradually relaxed capital controls and the interest rate differential in favour of RMB assets as compared to close to zero interest rates for USD assets, the inflow of capital is not surprising.

At the end of February 2014 the market was alerted of a weakening RMB. Although the decline was small, it was considered as 'a seismic shift' indicating some bigger moves ahead (Noble and Atkins, 2014a). The announcement of enlarging the fluctuation band to \pm 2 per cent came on 15 March 2014. The RMB was then trading on the weak side, but only until mid-August, so that, like in 2012, the effect of enlarging the fluctuation band weakened the market rate only temporarily.

According to sporadic observations internationally operating banks published in early autumn 2014 forecasts of an appreciating RMB at a rate of three per cent p.a. and issued financial instruments providing a boosted profit from an appreciating RMB against the USD with a limited risk of a loss (Nordea, 3 September 2014). So, the RMB strengthened in the market in autumn. The PBC either supported this movement by raising the value of the RMB slightly in its daily central rate quotations or stayed passive. It seems that the PBC did not want to discourage capital inflow. The RMB was trading on the stronger side of its fluctuation band until the latter half of November (Figure 6).

In 2014Q4 capital was flowing out from China for a third consecutive quarter. This holds for capital and financial accounts as well as for errors and omissions. These flows were larger than the current account surplus of 2.3 per cent relative to GDP so that the reserves diminished. The outflow can also be seen in the market spot rate that approached in December the weaker limit of the band (Figure 6).

\section{$2.4 \quad$ The latest changes}

Towards the end of 2014 the largest change affecting the RMB, USD and EUR since 2010 started to take effect: the EUR finally and persistently fell below its USD rate that prevailed on 18 June 2010. The downward spiral continued so that in mid-April, the time of writing, the EUR is down by 14 per cent.

This has crucial consequences for the external value of the RMB. The fall of the EUR (amplified by the fall of the JPY since 2012) means that in effective terms the RMB is in mid-April 201519 per cent stronger than on 18 June 2010 (JPM index in Figures 4 and 5), while it is 9 per cent stronger against the USD. The RMB market rate stayed at its weaker bound until March 2015 when the position seems to have eased somewhat although the spot rate still remained on the weaker side (Figure 6).

The fall of the EUR against the USD created a dramatically new situation. 


\section{New era has now started}

\subsection{Questioning the peg to the USD...}

Above, the data were looked at with emphasis on the RMB-USD rate. The reason was not that this would be sufficient analysis in all respects, but because the bilateral rate to the USD still dominates the policy of the PBC, the behaviour of market actors and analysis of market commentators. However, looking at the RMB-USD rates does not open the more fundamental issues regarding management of the external value of the RMB since June 2010 and in the new situation of early 2015.

As we noted above, the recent fall of the EUR together with the fall of the JPY since 2012 have, by mid-April 2015, made the effective exchange rate of the RMB 19 per cent higher than on 18 June 2010 when the management with reference to a basket was announced (JPM index in Figures 4 and 5), while it is 9 per cent stronger against the USD. So, an appreciation by ten percentage points is added from the cross rates between the other currencies as the result of the dominance of the USD in the basket used as 'the reference' by the PBC.

Now, the arguments of $\mathrm{Li}$ and $\mathrm{Yu}$ in spring 2010 referred to above have become newly relevant. Remember that their view was that the weight of the EUR in the basket used for managing the RMB should be increased in order to avoid an excessive appreciation of the RMB against a broad basket in the event that the EUR falls.

Oksanen (2012), triggered by the June 2010 announcement by the PBC to manage it 'with reference to a basket', discussed the various arguments in favour of pegging the RMB to a broader basket of the major currencies, referring to the evidence until early 2012. The idea of pegging to a broad basket is not new. Singapore is an example of a country that conducted this type of policy for several decades (Tee, 2013).

As we saw above, the PBC has continued to manage the RMB with reference to the USD, coupled with occasional trend-wise appreciation or other limited changes, and enlarging the fluctuation band to allow \pm 2 per cent deviation from the central rate.

In general, regardless of the current level of the external value of the RMB, for the largest or second largest economy in the world the reason for pegging almost uniformly to just one foreign currency, the USD, is questionable from the point of view of trading goods and services in all markets, including the European Union and the euro area. Gradual and smooth adjustment of the bilateral RMB-USD rate does not make things easier, but offers an opportunity for the speculators to gain at the expense of the Chinese economy (and the PBC). As also Ma (2015a and 2015b) points out, the USD has occasionally acted as a safe haven, and therefore appreciated in hard times, and thereby the effective pegging of the RMB to the USD has amplified the effect of external shocks on China's economy.

The developments since June 2010 showed that despite of smooth appreciation against the USD the effective value of the RMB first depreciated, which probably was not the intention of the authorities but a consequence of the depreciation of the USD against other major 
currencies. Then, the EUR has had its ups and downs since early 2010, due to overcoming the doubts regarding the viability of the euro zone and more stringent monetary conditions than in the US, until very recently, when the tide reversed and the EUR finally depreciated.

The RMB has arrived to its current external value partly by accident being the results of a combination of policies still dominated by controlling the RMB-USD rate and the uncontrolled movements of the other currencies of its major trading partners. The current moment is particularly suitable for a new orientation for two reasons: (1) the recent significant change in the USD-EUR rate highlights the importance of the composition of the basket used as the reference, and (2) the appreciation of the RMB over the past five years until recently may well mean that it is currently fairly valued as many commentators seem to think (e.g. Davies, 2014, Ma, 2015a and b, Kaminska, 2014, Keohane, 2015 and Yu, 2014) or even overvalued (Teague, 2015). ${ }^{3}$

\section{$3.2 \quad \ldots$ recognising the risks of free floating...}

This left open a variety of options. Free floating combined with completely free capital movements is favoured by a number of experts. The underlying arguments may have varied over the years. For those who considered that the RMB was undervalued, free floating was meant to have it appreciate. Apart from this, many economists see free floating as the best exchange rate regime in general also for China and recommend moving towards it even if not necessarily overnight.

However, there are those who warn against free floating of the RMB referring to China's specific conditions. Ronald McKinnon has forcefully argued in his many writings, including in the popular press (McKinnon, 2014), that both managed appreciation of the RMB and letting it float combined with liberalized capital movements would lead to disastrous consequences for China. In short, high potential growth keeps the expected rates of return high. If the RMB is made or allowed to appreciate, this feeds into expectations of further appreciation, which then leads to large capital inflows. The boom ultimately busts, followed by a long period of stagnation, like in Japan.

For McKinnon the RMB-USD has not been fundamentally wrong but the current account imbalances have rather reflected deficient saving in the US and excessive saving in China. Therefore, his main proposal has been to keep the RMB-USD rate fixed. He may have overdone this argument for the past as from 2002 to early 2008 the RMB probably first got and then stayed undervalued and this contributed to the imbalances even if they were not necessarily the only or primary source.

\footnotetext{
${ }^{3}$ Until late 2012 the RMB was hardly stronger in effective terms than in June 2010, but by spring 2015 it has appreciated by about 15 per cent (Figures 1 and 4). For example, Yu (2012) made a strong argument that China was running high current and capital account surpluses to the detriment of China's welfare; in Yu (2014) he considered that the RMB was already in early 2014 not far from equilibrium, and we may note that since then it has appreciated by about six per cent in effective terms.
} 
McKinnon proposed keeping the peg to the USD untouched and ignored the question about enlarging the RMB basket in the world where there are more actors than just the US and China. However, his warnings are pertinent. China still has a high potential for growth as its GDP per capita in purchasing power parities is just 25-30 per cent compared to the Western World. The process of catching up is long and exceeds the time horizon of the actors in the various markets, which easily leads to overshooting if the exchange rate floated freely. China is also so large that its problems would affect all others.

\section{3 … and keeping the 'reference to a basket', but to a broad basket}

This eclectic view means that China will still for a long time need to face the 'impossible trinity' since all three goals of an independent monetary policy, a fixed exchange rate and free capital mobility cannot be reached. However, which one of the three should be abandoned to achieve the two remaining ones is not a trivial question, and perhaps jumping to a theoretically ideal corner solution is not the wisest decision.

Ma (2015a and b), for example, forcefully takes the view that the pegging to the USD should be abandoned and the RMB should be allowed to float, with the PBC occasionally intervening into the market, 'leaning against the wind', to dampen the fluctuations. This can be considered useful advice, but its practical implementation will spur many questions. ${ }^{4}$

Regardless of competing arguments of various scholars on this issue we may relatively safely assume that for the Chinese authorities a freely floating RMB and complete liberalization of capital movements would be too dangerous an experiment. For them, gradualism is often an expression of cautiousness.

In these conditions, including cautiousness of the authorities, anchoring the RMB to a basket based on China's trade might be the best option for quite some time. Its primary benefit would be to isolate the Chinese economy from the fluctuations of the USD against the other major currencies. Another advantage is that it would somewhat limit the very short-term speculation as the transactions costs of trading a basket of currencies are higher than trading the USD for short-term profits.

The new RMB basket could be the SDR if a limited number of currencies with relatively deep markets be desired, or a modified basket with a larger weight for the JPY than in the SDR to reflect Japan's share in China's trade. It could also be a basket of a large number of currencies included in the calculations of effective exchange rate by the BIS derived from a sample of 61 countries. There are many options between these extremes, and the exact

\footnotetext{
${ }^{4}$ Here, we should recognise that the authorities impose various controls and intervene into markets in all the three areas above. Interventions in the foreign exchange market is the topic of the present paper, monetary policy uses quantitative controls and regulates the various interest rates. Regarding capital mobility, see Xu and $\mathrm{He}$ (2015) for a detailed account of liberalisation and the current state. In the Annex we present data on forward exchange rates for the RMB and conclude that also this segment of the markets is obviously still affected by interventions by the authorities.
} 
composition may not matter so much as the main issue is to enlarge it from the current USDdominated basket.

Pegging the RMB against a basket is not a silver bullet (and there is none). It would do away with the excessive dependence on the USD but also pegging to the basket would have to be adjustable. This has its advantages and disadvantages. If the fundamental factors change, the real exchange rate of the RMB needs to change and it is possible that adjusting the nominal rate against the basket would help. However, this can always lead to expectations of further adjustment and speculation. Also, adjusting the nominal rates gradually has the same disadvantages as under pegging to the USD, offering a one-sided risk for the speculators.

As the RMB might currently be fairly valued, announcing the broadening of the basket could be done without any initial adjustment to the daily rates. Hence, no expectations of further changes would be created.

A genuine widening of the basket would be a natural further step under 'managed floating with reference to a basket' repeatedly declared by the PBC. One further step would be to declare the composition of the new basket - transparency would obviously be beneficial to promote the use of the RMB as the risks of arbitrary policy changes would diminish. This would enhance international use of the RMB which has been a firm policy goal of the PBC. As one step the Chinese authorities aim at including the RMB in the SDR in the next revision of its composition later in 2015 (China Daily, 19 March, 2015). As the world's largest exporter China meets one of the two main criterion, but it is also required that the currency is 'freely usable'. The governor of the PBC has declared that by late 2015 China will liberalise capital movements further in order to fulfil this requirement (China Daily, 23 March, 2015).

We should note that being 'freely usable' does not mean that a currency needs to be freely floating. Anchoring the external value of the RMB to a basket could diminish the risks of entering to sudden crisis that could force introducing restrictions on the foreign exchange market.

\section{Composition of China's foreign exchange reserves}

Parallel to the composition of the basket for the daily exchange rate quotations for the RMB there is the equally important question of the composition of the foreign exchange holdings of the PBC. There are no official figures on this portfolio of USD 3.8 trillion (December 2014), but it is widely held that the share of the USD denominated assets is still more than a half. The liquidity of the markets and expected rate of return are naturally the two main guiding factors, but volatility is equally important. Risk management means diversifying. Here, it has two dimensions: move to a more balanced composition of the portfolio but adjust it smoothly as no-one knows the perfect moment. In addition, the PBC need to take into account that it is such a big player that its moves affect the market. It cannot reduce the share of the USD in its portfolio too rapidly as this would endanger the value of its initial USD holdings. 
The currency composition of China's foreign exchange reserves is treated as a state secret. In 2010 it was estimated to consist of USD 65 per cent, EUR 26 per cent, GBP 5 per cent, and JPY 3 per cent (Reuters, 2010). Although roughly these number have been referred to still in 2014 (Salidjanova, 2014, and Wildau, 2014), also estimates of a significant fall of the share of the USD to around 50 per cent have been presented (Casarini, 2012, and Rabinovitch, 2013). These numbers are not confirmed, but it is widely believed that China has cautiously shifted from USD to EUR and possibly to JPY.

It is also considered that this shift, if it happened, along with similar changes by some other counties like Russia and Saudi Arabia, may have in 2010-2014 supported the EUR against the USD (Davies, 2014, and Kaletsky, 2015), although the relative strength of the EUR has probably mainly resulted from various factors on the two sides of Atlantic. It is also possible that the relative strength of the EUR may have delayed China's decisions to shift towards EUR holdings.

The EUR-USD rate over the past twenty years puts the current situation into historical perspective (Figure 7 for the ratio of the real effective rates). When the PBC in June 2010 reintroduced its more flexible policy, the EUR-USD rate was close to its long-term average despite the shadow of the Greek problem. Then, contrary to fears by $\mathrm{Li}$ and $\mathrm{Yu}$ at the time, the EUR first appreciated against the USD until spring 2011. By summer 2012 it had fallen back to its long-term average. Again, it was there but not any weaker, when the existential threats regarding the single currency emerged. The announcement of the ECB on 26 July 2012 to be 'ready to do whatever it takes to preserve the euro' restored the confidence and the EUR strengthened nearly ten per cent against the USD in six months. So, the EUR was at or above its long-term average from mid-2006 until late 2014.

The fall below the long-term average level started in December 2014 and continued further in 2015. At the time of writing it is about 19 per cent below its historical average (see the last observation from 15 April in the graph).

Regarding timing, the arguments to adjust the composition of China's foreign exchange portfolio are now stronger than ever since 2006. As liquidity of the market in each currency is required for managing the reserves, the main currencies must form most of the reserves. The SDR basket is a serious option by its construction. Its composition is based on a transparent methodology reflecting global trade flows and financial markets. At the current exchange rates (March 2015 averages) its composition is: USD 48, EUR 33, JPY 7 and GBP 12 per cent. The PBC will hold some other currencies for various bilateral reasons, also by reciprocity as other central banks are holding RMB assets. 


\section{Figure 7. Ratio of EUR and USD real effective exchange rates}

January 1994 - March 2015 monthly averages, Jan 1994 - Dec 2014 average = 100

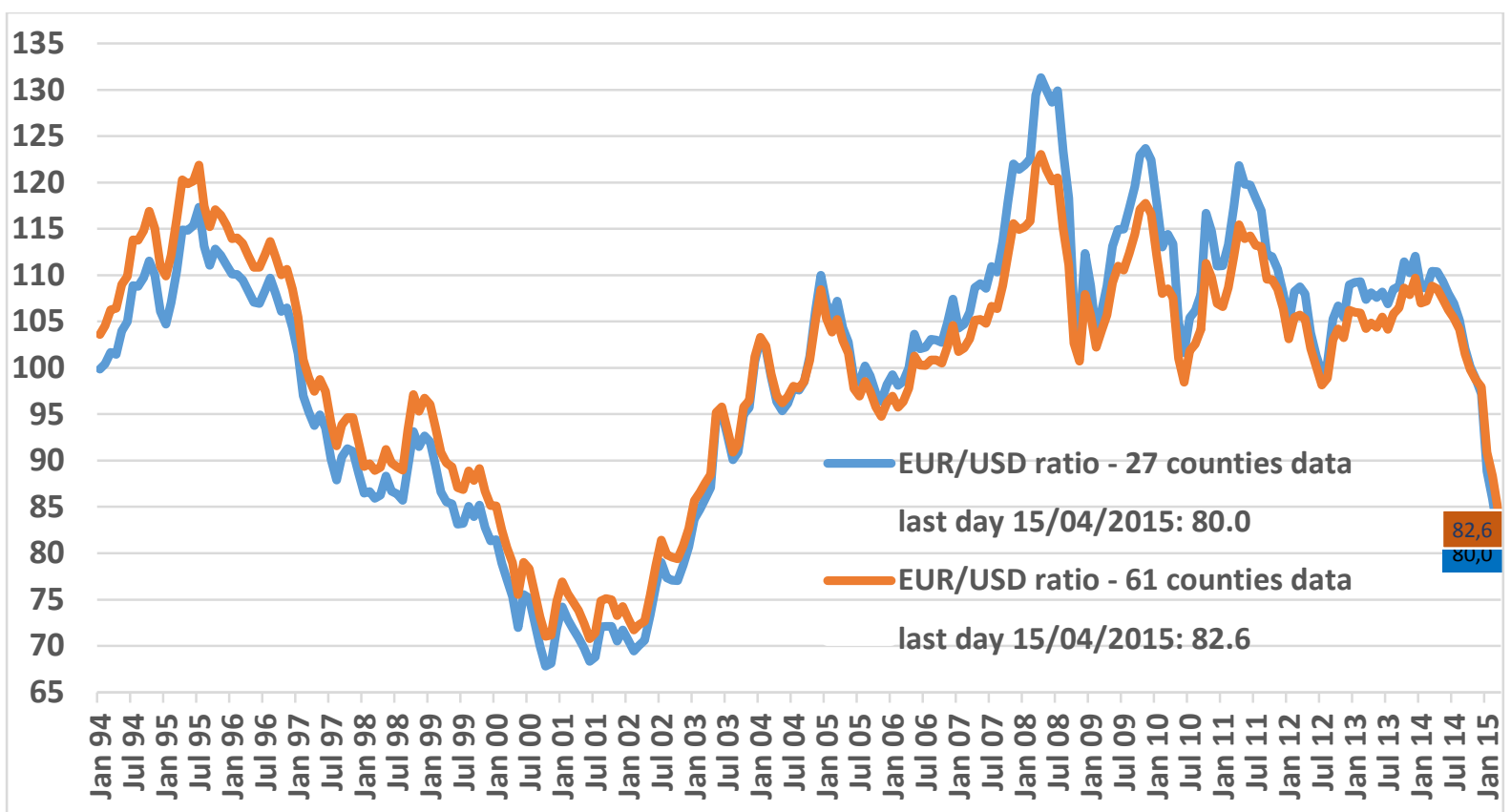

Legend: Two parallel measures, based on data covering 27 or 61 countries. Last day: estimates based on March 2015 average figures and EUR-USD exchange rate on 15 April 2015.

Source: Bank for International Settlements.

If management of the external value of the RMB was changed by pegging it to a genuine basket and the SDR basket were considered to be an efficient solution, then this could also guide the composition of the reserves. Additionally, the proximity and economic importance of Japan would possibly be taken into account by China's authorities.

These considerations concern the possible target for adjusting the composition of China's foreign exchange reserves in the long term. It is another question when and how to make the adjustment given the initial disproportionate weight of the USD. Here, the value of the EUR against the USD in mid-April 2015, some 19 per cent below its long-term average, is a factor in favour of shifting to EUR assets. China's foreign exchange reserves are large enough for China's moves to affect the market. In the current situation shifting to EUR holdings could possibly stabilise the EUR-USD rate. As the fall of the EUR ended in March 2015 the PBC may have already made such moves. This will not be known even in retrospect, but taking into account China's own interest this cannot be excluded. 


\section{Summary and conclusions}

Pegging the RMB to the USD since 1994 has characterised China's exchange rate policy, under either a fixed peg or appreciating crawling peg. The principal features of China's relations with the rest of the world - and its problems - have to a significant extent ensued from this. From early 2002 until July 2005 the RMB depreciated in effective terms, i.e. against any reasonable basket of currencies representing China's trading partners. It remained weak until early 2008 even if it appreciated against the weakening USD.

Over this period, 2002-2008, China's current account surplus increased and reached close to 10 per cent relative to GDP in 2007-2008. This contradicts the view that a fast growing economy with high investments would instead normally show a deficit on its current account. This and capital inflows led to a huge foreign exchange reserve, up to 40 per cent relative to GDP. Many commentators thought at the time and still think that this was not in China's own interest. It also created tension with its trading partners, notably with the US.

In retrospect we may think that all this was not a result of deliberate policy by the Chinese authorities, but rather followed from the fluctuation between the USD against other major currencies, and from pegging the RMB to it. We should not exaggerate this argument as the Chinese authorities always had an option to make changes to the RMB-USD rate, as they also did from July 2005 to July 2008 and again from June 2010 onwards. However, these changes remained modest, so that until 2012 the RMB had appreciated against a trade-weighted basket only moderately, hardly corresponding to a balanced adjustment in a fast-growing catching up economy.

Since 2012, especially after December 2014 when the EUR started falling against the USD the situation changed dramatically. Against a trade-weighted basket the RMB is now in midApril 19 per cent stronger than on 18 June 2010 when the current policy of managing the $\mathrm{RMB}$ with reference to a basket was announced, while it is 9 per cent stronger against the USD. So, ten percentage points arise from changes in the cross rates of the other currencies beyond the control of the PBC.

This, coupled with the story above covering 2002-2012, leads to the conclusion that the PBC could seriously consider abandoning the peg to the USD and begin managing the external value of the RMB with reference to a genuine broad basket. Fluctuations around the central rate defined as the RMB value of the basket would be allowed. Interestingly, although this policy option is quite straightforward and also mentioned in the active discussion on the $\mathrm{RMB}$, it is not the dominating proposal. Instead, obsession with using the USD as the unit of account in looking at exchange rates, including presenting their forecasts, still prevails. This is both unnecessary and often misleading as the effective rate of each currency is more relevant for most economic aspects (except outright short-term speculation).

A system where a genuine broad basket would replace the USD as a new anchor both for the PBC and for the market actors in daily operations could be more transparent and more endurable than other intermediary solutions proposed for the PBC. For example, letting the 
RMB-USD rate move relatively freely, the PBC leaning against the wind when appropriate, is an advice that leaves important questions open regarding its practical implementation.

Managing the RMB with reference to a genuine basket could be a suitable and most likely intermediary regime for the time being as the Chinese authorities probably are reluctant to take the risk of jumping to free floating - both theoretical and practical arguments still speak in favour of gradualism and cautiousness in managing an economy which is still in transition. This could, as China is a large economy, in the best case provide stability also for its partners.

Diversifying further the currency composition of the foreign exchange reserves and other foreign assets of the Chinese government, from USD towards EUR and JPY assets, would be a natural parallel shift. The current EUR-USD-JPY exchange rates may offer a good opportunity to carry out this move. 


\section{ANNEX}

\section{The RMB forward rates as an additional source of monitoring the market}

The forward exchange rates of currencies provide information on market conditions. Especially if the markets are free and deep the forward rates respond to the expectations of currency movements and interest rate differentials. We know that the RMB markets are still restricted, but the forward exchange market exists and may provide additional information on the market conditions. In the forward market the RMB traded at a premium (less RMB for one USD) in spring 2010 and this continued until late summer 2011. This is consistent with expectations of RMB appreciation (Figure A1).

Then, from late 2012 to early 2014, fairly consistently, the RMB was trading at a discount. This cannot be explained in simple terms as over this period the RMB continued to appreciate fairly steadily (see both the PBC central rates and those on the market in Figure 5 and the market rates in Figure A1). As soon as this became expected, the forward rates should have been lower than the spot rate.

Searching for an explanation we may note that the Chinese exporters, who from late 2012 to early 2014 hedged their future USD revenues in the forward market, were gaining, while the international speculators who invested in RMB were obviously not interested in hedging their RMB assets on the forward market as they expected the RMB to appreciate. Thus, more complex factors must have determined the forward rates. During 2013 the market spot rate was on the stronger side of the fluctuation band (Figure 6) due to capital flowing in (Figure 3 ). Was it expected that the market spot rate would move towards the PBC central rate and the latter was not expected to move much?

These or any other explanations based on expectations may not be accurate. Maybe the government controlled Chinese financial institutions deliberately wanted to favour the Chinese exporters and the forward rates did not reflect demand and supply. Note that in summer 2013 the forward rates were even higher than the PBC central rate. So, the exporters who hedged their revenue on the forward market received even more than the central rate at the time of making the contract.

The pattern of the forward rates may reveal that international financial transactions are still far from market determined despite the gradual liberalisation (Xu and He, 2015). The rates of growth and return on capital in general are so different in the respective counties. The constantly positive interest rate differential in favour of RMB assets in the mainland as compared to USD assets in international markets has meant that opportunities for arbitrage and one-sided risk taking have been available to some actors but not for all. Thus, the forward exchange market not displaying the average expectations may well be one expression of incomplete markets. 
Figure A1. RMB-USD spot rate and forward rates for 3, 6 and 12 months, daily 2010-

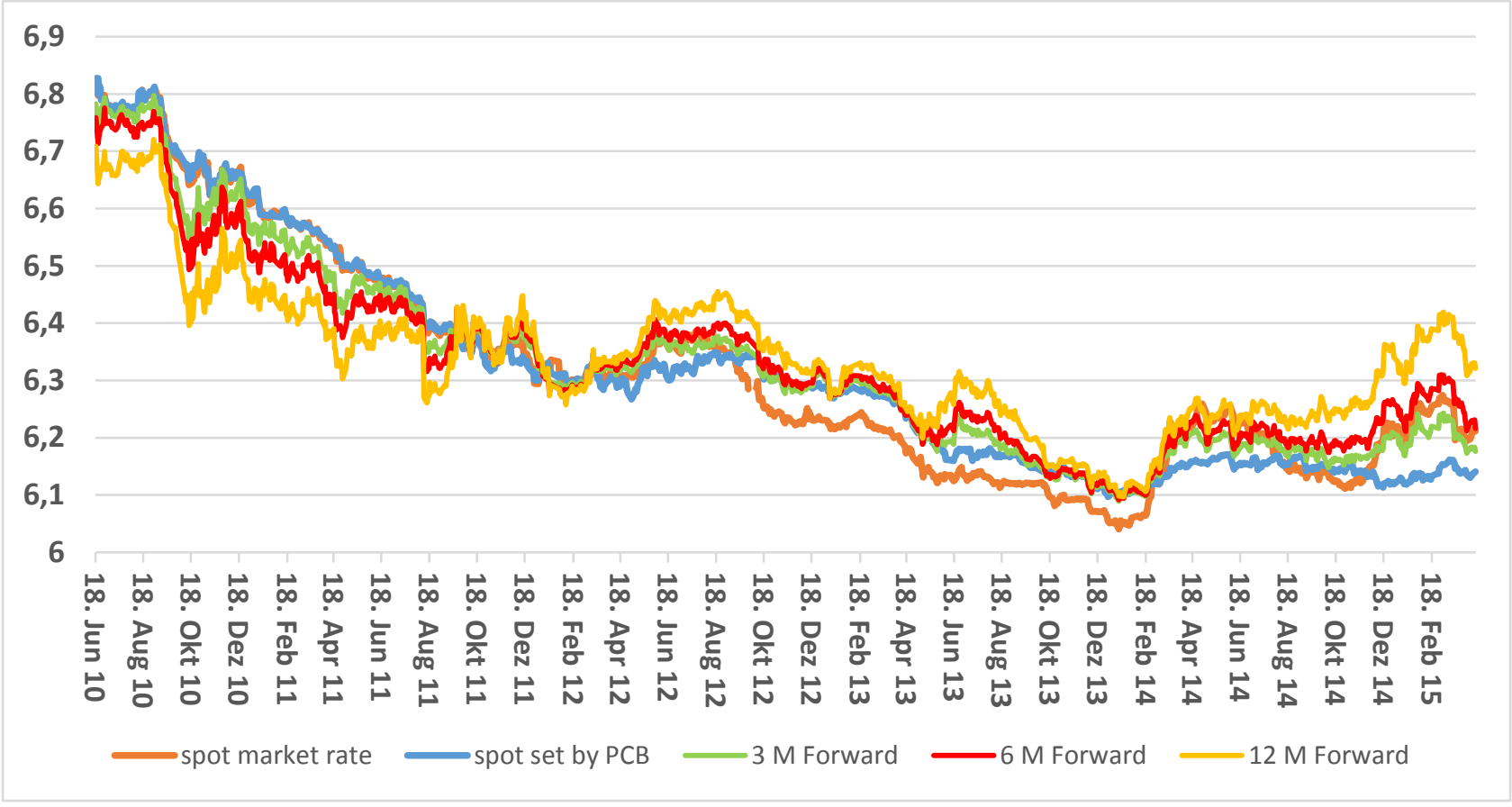

Legend: daily observations, 4 January 2010 - 14 April 2015.

Source: Bloomberg.

Anyway, it is interesting look in retrospect at what happened from early 2014 onwards. The RMB weakened in the spot market so that the outcome from the previous forward contracts turned to losses. For example, the Chinese exporters who had sold their USD revenues in the forward market would have done better by not doing so (see Figure A1: from mid-March 2014 until a few months later the spot rate for RMB against USD was higher than the 3 and 6 months forward rates 3 or 6 months earlier, respectively; for the 12 month forward rate this was not so). The loss was highest, 2.5 per cent, from a 3-month forward contract signed in the beginning of February.

Seen this way the outcome was not necessarily damaging, but it is known that the financial products on the market were more complex and potentially produced much higher losses. Noble and McGee (2014b) wrote in March 2014, when the RMB depreciated in the wake of the PBC decision to enlarge the fluctuation band, that the fall of the RMB 'would cause heavy losses on billions of dollars of complex hedging products taken out by Chinese companies - often exporters - that wanted to bet on renminbi appreciation'. This is possible as some financial products may have been geared to multiply the effect of a change in the RMB-USD rate.

As we saw above, the weakness of the RMB did not last for very long, but the RMB appreciated again from May through November 2014. Like in 2013 the forward rates were again tempting for the Chinese exporters. 
When depreciation of the RMB started in December 2014, coupled with the much greater depreciation of the EUR against the USD, the previously made forward contracts again turned unfavourable for the Chinese exporters. The outcome from the most recent contracts are not known yet as their maturity is still ahead.

Our very last observation is that now in 2015 the RMB is weaker as compared to the spot market rate for 6 and 12 months, but stronger for the 3 months. This pattern may reflect a view that the RMB would appreciate in the short term towards its central rate set by the PBC, but over longer term be on the track to depreciate slowly.

\section{References}

Casarini, Nicola (2012), 'China’s Approach to US debt and the Eurozone crisis', in China's Geoeconomic Strategy, LSE !deas, Special Reports 12, June 2012.

China Daily, 19 March 2015, 'How SDR status can boost renminbi internationalisation'.

China Daily, 23 March 2015, 'Central bank chief: 'It's time to free up the yuan'.

Davies, Gavyn (2014), 'China’s changing exchange rate policy’, Financial Times, 4 May 2014.

Kaletsky, Anatole (2015), 'How far will the euro fall’, Project Syndicate, 17 March, 2015.

Kaminska, Izabella (2014), 'More on the overvalued renminbi', Financial Times, 7 October 2014

Keohane, David (2015), 'This currency would be great if it wasn't for the market, RMB edition’, Financial Times, 4 February 2015.

Noble, Josh and Ralph Atkins (2014a), 'Renminbi’s fall marks seismic shift', Financial Times, 28 February 2014.

Noble, Josh and Ralph Atkins (2014b), 'Renminbi rate hits 'red line' level for losses', Financial Times, 19 March 2014.

Ma, Guonan (2015a), 'The aging dollar peg: time for the PBC to bid it farewell - the Chinese economy is simply too big to remain tied to this once useful monetary anchor - it's time to let it go’, Bruegel Analysis, 19 February 2015.

Ma, Guonan (2015b), 'Guest post: time to ditch the renminbi-US dollar peg', Financial Times, 23 February 2015.

McKinnon, Ronald (2014), 'China’s currency conundrum’, Project Syndicate, 11 April 2014

Nordea (2014), 'Sijoitusobligaatiot', 3.9.2014.

Oksanen, Heikki (2012), 'Re-pegging the renminbi to a basket: issues and implications', Asian-Pacific Economic Literature, May 2012, pp. 18-33, at http://www.researchgate.net/profile/Heikki_Oksanen/publications; working paper version published as CESifo Working Papers No. 3254, November 2010. 
Rabinovitch, Simon (2013), 'Beijing furious over impasse, say officials', Financial Times, 12-13 October 2013.

Reuters, 3 September 2010, 'Heavy in dollars, China warns of depreciation’.

Reuters, 7 September 2010, 'Strong yuan would hurt China: economists'.

Salidjanova, Nargiza (2014), 'China's Foreign Exchange Reserves and Holdings of U.S. Securities’, USCC Economic Issue Brief, No. 2, March 21, 2014.

Teague, Solomon (2015), 'Rising dollar makes renminbi second-most overvalued currency', Euromoney, 13 February 2015.

Tee, Ong Chong (2013), 'An Exchange-Rate-Centred Monetary Policy System: Singapore's Experience', in Market Volatility and Foreign Exchange Intervention in EMEs: What Has Changed?, BIS Paper No. 73, October 2013.

Wildau, Gabriel (2014), 'China's large forex reserve holdings both blessing and curse', Financial Times, 30 September, 2014.

Xu, Quiyan and Fan He (2015), 'The influence of RMB internationalization on the Chinese economy, theory and policy’, CIGI Papers No 58, February 2015.

Yu, Yongding (2012), 'Rebalancing the Chinese economy', Oxford Review of Economic Policy 28 (3): 551-568.

Yu, Yongding (2014), ‘Reviving China’s rebalancing’, Project Syndicate, 7 February 2014.

The official announcements of the Peoples’ Bank of China in June 2010, April 2012 and March 2014:

http://www.pbc.gov.cn/publish/english/955/2010/20100622144059351137121/20100622144059351137121_html.

http://www.pbc.gov.cn/publish/english/955/2012/20120414090756030448561/20120414090756030448561_html

http://www.pbc.gov.cn/publish/english/955/2014/20140317160839706274217/20140317160839706274217 .html 